\title{
Two Essential Elements for a Strong and Sustained Industry in the ECOWAS Area
}

\author{
Babacar Ndiaye \\ Amadou Mahtar MBOW University, Dakar, Sénégal \\ babacar.ndiaye@,uam.edu.sn \\ Daniela Ancuta Sarpe \\ Dunarea de Jos University of Galati, Romania \\ daniela.sarpe@ugal.ro \\ Cyril Manga \\ Cheikh Anta Diop University, Dakar, Sénégal \\ cyrilmanga88@gmail.com.
}

\begin{abstract}
This article proposes a contribution to the literature by theoretically analysing two essential elements for a strong and sustained industry in the Economic Community of West African States (ECOWAS): exploitation of natural resources and access to electricity. Beyond the place that industry occupies in the economy, the study shows that these two essential elements make it possible to justify the industrial emergence of ECOWAS. Our analysis shows that the industrial sector generates jobs, increases incomes and the value of agricultural products and promotes technological progress. It also opens up economic prospects for agents and provides the states with revenue allowing them to feed their accumulation funds.
\end{abstract}

Keywords: industry - natural resources - electricity - ECOWAS.

JEL classification: N50, L90, P18.

\section{Introduction}

The African continent is rich in natural and mineral wealth, whose better valorization and efficient use could bring about changes in the final demand, intermediate demand and international trade. Therefore, these natural and mineral riches represent a significant potential for economic development. The African industrial sector, which should be one of the supreme levers in the economic structure, remains underdeveloped and undiversified, with a low valuation of continental resources. According to the AfDB (2018), the African industry generates only 700 US dollars of the GDP per capita on average, three times less than in Latin America (2,500 dollars) and five times less than in East Asia (3,400 dollars). Nowadays, more than half a century after the independence of African countries, Ben Amar (2013) indicates that the continent is still an exporter of raw materials to the industrialized countries as other regions increase their share of non-oil exports. The latter transform and resell these products in Africa at considerably higher prices.

In this context, it is important to address the above-mentioned challenge on Africa, especially in the ECOWAS, which is marked by embryonic economies far from being able to compete with developed economies. Indeed, an analysis that implements the essential factors for a strong and sustained industry in this region is undoubtedly one of the ways to help take up this daunting challenge. It is with this in mind that this article is made.

In the ECOWAS, the industry is able to greatly contribute to the sustainable decline of the borders of poverty through its power to create jobs, increase revenues and the value of agricultural products, to promote technological progress, open up economic opportunities for vulnerable groups (especially women) and generate significant revenue for the State budget. According to the AfDB (2018), no country in the world has achieved prosperity or a decent 
standard of living for its citizens without a strong industrial sector. For Niosi (1988), the country with the most competitive manufacturing industry will most likely be the one with the most efficient banks, insurance or engineering firms.

This paper aims to highlight two essential elements that promote a strong and sustained industry in the ECOWAS: exploitation of natural resources and access to electricity. The analysis of these two elements resides, above all, in the identification of the paths leading the region towards industrialization, which will have to ensure, in the near future, the selfsufficiency and the reduction of the dependence of ECOWAS States on advanced countries. Industrialization in the ECOWAS is a way to help its member countries catch up and reach the same level of development as other economies.

The paper is structured as follows. The first section proposes a theoretical analysis of the notion of industry. The second section analyses the process by which industry contributes to economic emergence. The third section shows how the exploitation of natural resources and the access to electricity contribute to a strong and sustained industry in ECOWAS.

\section{Concept of industry and its evolution}

According to Musso (2014), the concept of industry comes from the Latin word instruere "which prepares, meditates, shapes in itself". In fact, for a long time designated by the skill, the talent and the ingenuity related to a know-how, a second meaning later appeared for this term of industry to qualify a trade, a profession, a work, even an art. Then, by extension, the word has identified all the operations that contribute to the production and circulation of wealth. In the $18^{\text {th }}$ century, the term was commonly used to designate zeal or application to work as well as the productive activity and its result (Musso, 2014).

Historically, the industry refers to the productive act, that is to say, it is basically a matter of transforming materials into goods and services. The focus here is on the material, physical, tangible dimension of the process. The traditional places of industry are therefore, on the one hand, the factory that is a site of mass production, of unique concentration of labour and capital and, on the other hand, large companies, groups, multinationals represented by their head office or their main location (Le Blanc, 2005). Leger (2009) considers industry as the balance of payments, which provide us with the means of progress, and productivity that increases the purchasing power. Buzenot (2013) sees industry as a means of diversifying the structures of the economy so as to make them less vulnerable to commodity market conditions. According to the definition given by the National Institute of Statistics and Economic Studies (INSEE), "those economic activities that combine factors of production (...) to produce material goods for the market are industry-related." 107 . Goods are "physical objects for which there is a demand, over which property rights may be established (...)" (Fontagné et al., 2014).

Although some authors have tried to give meaning to industry, it is nevertheless crucial to specify that this term is, according to Kassé (2013), a theological concept that has not had a precise and widely accepted definition. For him, the dictionaries of economic sciences that swarm do not establish a consensual definition, but still reveal two understandings that can be found in the economic thinking. The first explanation is sectoral and emanates from Colin Clark, who divided all productive activities into three sectors (primary, secondary and tertiary). According to this author, the industry of a secondary sector is "the continuous transformation, on a large scale, of raw materials into convertible goods". So, for him, industrialization will then be considered as the increase in the size of the industrial sector. The second definition, which is based on technology-related aspects, incorporates the productive techniques of industry. Starting from this, Kassé (2013) cites the works of Perroux (1962), Rostow (1990) and Giersch (1979) to shed more light on the notion of industrialization. In

\footnotetext{
${ }^{107}$ https://www.insee.fr/, section "definitions and methods" (accessed on December 15 $5^{\text {th }}, 2017$ ).
} 
fact, for Perroux (1962), industrialization is "the structure of a whole economic entity by the use of machinery with the intention and effect of increasing cumulatively and at a decreasing cost an individual effort, the power of a group to obtain objects that are beneficial to them". As for Rostow (1990), he considers that "industrialization is the systematic, generalized, progressive application of science and technology to the production of goods and services".

Thus, Kassé (2013) notes that industrialization is not a production sector, but rather a way of producing, characterized by the rational use of machines operating at decreasing costs. As for Giersch (1979), he shows that industrialization is the modern form of expansion and progress by defining it by two characters: the mechanization of production and the increase of the division of labour, that is specialization. This latter definition better reflects contemporary industrial realities marked by an extraordinary widening of the scope of industry: banking or tourism industry, green industry and to which, Sutherland (2003), the United Nations Special Representative of the Secretary-General for Migration, adds the industry of immigrants (June 2006) that represents the financial and technological contributions of the diaspora (Kassé, 2013).

Obviously, this semantic precision of the concept of industry illuminates that of industrialization, which is "the entire manufacturing process of manufactured products that goes from the prototype to the series looking for a high labour productivity. It makes it possible to replace the artisanal or manual production system in dispersed locations via centralized production using machines and applying standards to obtain products of uniform quality". In the end, we understand that industrialization is conceived as a process of increasing industrial activities and a transformation of production methods through the use of machines. Therefore, it is not just a question of producing, but of being so competitive to hope to take advantage of the increasingly open and competitive globalized markets. This competitiveness needed to access internal and external markets depends on the availability of qualified human resources, natural potentialities, sustainable economic and energy infrastructures favourable to making commercial decisions on the markets. It also depends on the incentive frameworks that the public authorities implement to make the space attractive and profitable to private and public investments (Kassé, 2013).

For the AfDB (2018), industrialization boosts productivity by introducing new techniques and technologies, creates jobs, enhances the skills of the workforce, fosters the formal economy, improves the economy in general and contributes to social stability. Industrialization can improve the trade balance by creating export goods and stimulating local competition for imports.

To better understand this concept of industry, Kassé (2013) indicates that the industrial sector includes, in the broad sense, mining, oil, construction, public infrastructures and manufacturing transformations.

\section{Place of industry in the economy}

In his article entitled "Industry in the French economy (1978-2003): a comparative study", Le Blanc (2005) considers that the role of industry lies mainly in the economy as a whole with its major spillover effects ${ }^{108}$. This is what describes throughout the $20^{\text {th }}$ century the exceptional place occupied by industry in economic analyses and perceptions despite a never dominant relative weight. These spillover effects spread through three essential channels: i) intermediate consumption, both in industry and in services; ii) productivity gains, the dynamics of which

\footnotetext{
${ }^{108}$ Deubel (2008) considers the spillover effect as a mechanism by which the growth of a sector is supposed to lead to the expansion of other sectors of the economy due to the importance or the technological advance of the leading sector. This effect requires the emergence of positive externalities (technological innovations that will benefit the production techniques of the entire economy for example). A virtuous circle of growth is then established where each sector of the economy leads to the expansion of others by binding effects.
} 
feeds at the same time an uninterrupted decline in industrial prices, growth in demand, the expansion of mass consumption to a growing number of goods, and the parallel rise in the living standard and corporate profits; iii) innovations, of which industry is a crucible and a field of privileged experiences before a wider diffusion to the rest of the economy. Le Blanc (2005) also points out that Adam Smith, David Ricardo and the theoreticians of international economy have illustrated the benefits of the interstate division of labour and productive specialization around examples of raw materials and manufactured goods. Bordigoni (2012) quotes the work of Le Blanc (2009) to announce that, in industrialized countries, industry remains a driving force of the economy by its importance in exports and thus in the trade balance of a country. Worldwide, most of the world's trade is represented by trade in manufactured goods. In France, around 80\% of exports are made by industry (Bordigoni, 2012).

In addition, Boucher (1973) mentions that England was at the time a model to emulate for less industrialized countries or, more specifically, it generated a demonstration effect on the latter. This is manifested by the ostentatious need of each country to produce manufactured goods and the belief that industrial activity generates various beneficial effects of overflow. In fact, according to Friedrich List (1827), quoted by Boucher (1973), England, an industrialized country, has "a thousand advantages" over other nations. It would be favoured in many ways by "a greater experience in the commercial field", by "improved operating techniques", by having a "learning system related to the needs of the industry", an "advanced education system", and also "skilled and trained workers", by "the most perfect machines and the least expensive", the "cheapest means of communication", a "good availability of credit for manufacturers", "the lowest interest rates". In addition, it has access to a "huge domestic market" as well as an "important export market". Notwithstanding, List (1827) infers that, in a broad sense, industry improves the sociological, political and cultural characteristics of a nation, while not failing to emphasize the importance of industrialization, consequence of the industrial progress (Boucher, 1973).

To abound in the same direction, the Report of the African Development Bank (2017) foreshadows that industrialization is fundamental for economic development. According to this Report, no region or country in the world has ever achieved prosperity and a decent socio-economic status for its citizens without the development of a robust industrial sector. This is the reason why African leaders have repeatedly stressed the importance of "industrialization" for an inclusive and resilient growth of the continent (AfDB, 2017). From this perspective, Africa's industrialization is included in the priorities of the G20 to promote new opportunities such as Innovation, Digital Economy and the New Industrial Revolution (Financial Afrik, 2016). UNIDO's Industrial Development Report 2013 states that only sustainable and inclusive industrial development can give to the countries of the world, whether industrialized or developing, the means to achieve socially equitable and ecologically sustainable economic growth, generating jobs and income, which will produce the wealth needed to achieve broader development goals in the areas of health, education and human rights (UNIDO, 2013). According to Kassé (2013), today's developed countries are those with a high level of industrialization. The process of industrialization can change the structure of modern economic activities and can be seen as a source of positive externalities for the other sectors (Amar, 2013). Industrialization can be appreciated as an essential tool in creating jobs, reducing poverty and promoting regional development policies. Moreover, it is able to stimulate technological progress and innovation that can be considered as productivity gains. For him, if developed countries have supported their industries through targeted policies and appropriate investments in their institutions, it is because they have discovered the crucial role of industrialization, included by the large part of the industrial sector in the GDP. Fontagné et al. (2014) explain that in France the observation of the return of a voluntarist speech on industrial policy or even a direct intervention on industry has meant that the research is carried 
out mainly in the industry. It is in this sense that in $2010,80 \%$ of the domestic research and development ( $R$ \& D) spending in companies was concentrated in industrial branches, compared with $18 \%$ in service industries. They define research as one of the pillars of sustainable growth. By spending on $\mathrm{R} \& \mathrm{D}$, companies and the state invest in the production of knowledge, generating new products or manufacturing processes that allow companies to remain competitive in manufacturing costs, quality and product diversification. In the long run, this knowledge translates into productivity gains and increased welfare.

\section{Exploitation of natural resources and access to electricity to improve the industrial sector}

The intensification of the exploitation of natural resources and widespread electrification are essential to improve the industrial sector. According to Sarpe et al. (2017), the low level of improvement in the industrial growth rate in ECOWAS can be generally explained by the deficit of valorisation of the natural resources. Nevertheless, West Africa is a major producer of agricultural products. According to Weigert (2016), West Africa produces and globally exports $65 \%$ of cocoa beans worldwide. But, since it does not transform them, it only benefits from $3.5 \%$ to $6 \%$ of the final price of a chocolate bar. Specifically, ECOWAS (2010) foreshadows that Côte d'Ivoire and Ghana are the world's first and second largest producers of cocoa with respectively 1,200,000 tonnes / year and 700,000 tonnes / year during the decade 1999-2009. Endogenous processing of this product does not exceed $20 \%$. In addition, all countries in the region produce cotton to varying degrees. Mali is the largest African producer with an average of 600,000 tonnes / year in the decade 1999-2009, and it barely transforms $2 \%$ of its production.

Furthermore, in ECOWAS, the population is growing, and many of those living in rural areas have difficulty accessing electricity networks. This precarious supply of electricity represents a shortfall for the industry, but also for local economies. Indeed, the fight against the problem of access to energy for all is a priority for the populations. It would also promote the competitiveness of the local industry. In short, energy is an important factor for the development of mass transportation.

\section{Conclusion}

This article shows that access to electricity and the benefits derived from natural resources are of paramount importance for improving the industrial sector in the ECOWAS region. The theoretical approach provides a better understanding of concepts related to industrial development.

In ECOWAS, the development of the industrial sector is explained by the exploitation of natural resources. Thus, an intensification of the exploitation of natural resources through a considerable improvement in the processing of agricultural products, for example, helps the industrial sector to play its full role. In fact, a policy leading to improved resource processing is to increase the number of infant industries in the region. Moreover, the removal of unconventional barriers between the different countries of the area improves the fluidity of intra-regional trade and promotes the consumption of local products. Adopting a systemic approach must enable all ECOWAS countries to work in synergy to better benefit from the exploitation, processing and marketing of its resources.

Beyond the rationalization of the exploitation of natural resources to promote industry in the ECOWAS region, extended electrification remains a priority in order to improve and diversify energy sources. To this end, the promotion of renewable energies, especially solar photovoltaic energy, wind energy, hydroelectricity, must be the subject of a priority policy. 


\section{References}

1. BAD. (2018). "Les cinq hight pour transformer l'Afrique ». Mai, 24 p.

2. BEN AMAR, Mobamed. (2013). Le rôle de l'industrialisation dans la croissance économique: une analyse comparative entre les pays nord africains et les pays subsahariens. Revue européenne du droit social, $n^{\circ} 20$, p. 219-233.

3. BUZENOT, Laurence. (2013). Caraïbe et île Maurice - Industrialisation et développement. Editions L'Harmattan, novembre, $206 \mathrm{p}$.

4. FONTAGNE, Lionel et al. (2014). Pas d'industrie, pas d'avenir ? Les notes du conseil d'analyse économique_[en ligne], $n^{\circ}$ 13, juin, 12 p. [consulté le 06 novembre 2017]. URL: bttp:// wmw.caeeco.frl.

5. KASSE, Moustapha. (2013). L'industrialisation africaine est possible : quel modèle pour le Sénégal ? Paris : L'Harmattan, 438 p.

6. BORDIGONI, Mathieu Thomas. (2012). Détermination du rôle de l'énergie dans la compétitivité de l'industrie manufacturière : Etudes économétriques et modélisation des interdépendances. Thèse de doctorat: Economie et finance. France : Ecole Nationale Supérieure des Mines de Paris, 11 octobre, 420 p. [Consulté, le 16 mai 2017]. URL : bttps://pastel.archives-ouvertes.fr/pastel-00803187.

7. BOUCHER, Michel. (1973). List et la théorie de l'industrie naissante. L'Actualité économique [en ligne]. Vol. 49, $n^{\circ}$ 2, p. 259-268 [consulté le 16 juin 2016]. URL: bttp://id.erudit.org/iderudit/802996ar.

8. BAD. (2017). "Les Top 5 : industrialiser l'Afrique ». Avril, 08 p.

9. Financial Afrik. L'industrialisation de l'Afrique dans les priorités du G20 pour la Nouvelle Révolution Industrielle [en ligne]. Mise à jour le 17 juillet 2016. [Consulté, le 30 novembre 2017]. URL: bttps:// wmw.financialafrik.com/2016/07/17/ lindustrialisation-de-lafrique-dans-les-priorites-du-g20pour-la-nouvelle-revolution-industrielle/\#.V4u3shm $2 \times A g$.

10. LE BLANC, Gilles. (2005). L’industrie dans l'économie française (1978-2003): une étude comparée. Cercle de l'industrie / Institut de l'entreprise. France : Paris. Avril, 112 p.

11. LE BLANC, Gilles. (2009). L'industrie dans l'économie (1981-2006): une réalité pour notre avenir ? Etude comparée de l'industrie en France et dans les grandes puissances industrielles depuis 25 ans [en ligne]. Cercle de l'industrie / Institut de l'entreprise. Paris, Janvier, 46 p. [Consulté, le 15 décembre 20177. URL: http:// www.cercleindustrie.eu/fr/publications/etude-du-cercle-de-lindustrie-lindustriedans-leconomie-francaise-1981-2006-une-realite/.

12. LEGER, Jacques. (2009). L'avenir de notre industrie - Construire une mondialisation durable. Editions AFNOR. 520 p.

13. MUSSO, Pierre. (2014). L'imaginaire industriel. Editions Manucius. 50 p.

14. ONUDI. (2013). "Rapport sur le développement industriel 2013, Soutenir la croissance de l'emploi : Le rôle du secteur manufacturier et du changement structurel. Un tour d'borizon ». $46 \mathrm{p}$.

15. CEDEAO. (2010). "Politique Industrielle Commune de l'Afrique de l'Ouest (PICAO) ». Nigéria: Abuja, juillet, 84 p.

16. NIOSI, Jorge. (1988). L'industrie américaine au carrefour. Cabiers de recherche sociologique [en ligne], volume 6, $n^{\circ}$ 1, p. 41-61, [consulté, le 26 juillet 2018]. Doi:10.7202/1002038ar.

17. DEUBEL, Philippe. (2008). "Les stratégies du développement ». France: Pearson Education-Analyse économique et historique des sociétés contemporaines, p. 463-513.

18. SARPE, Daniela Ancuta et al. (2017). Contribution of the Industrial Structure to Economic Growth: the Case of ECOWAS. Annals of "Dunarea de Jos" University of Galati-Annals of "Dunarea de Jos" University of Galati - Fascicle I. Economics and Applied Informatics - Years XXIII [en ligne], $n^{\circ}$ 3, décembre, p. 148-157. URL: bttp:/ / www.eia.feaa.ugal.ro/.

19. WEIGERT, Maxime. L'industrialisation en Afrique de l'Ouest: état des lieux [en ligne]. Mise à jour le 03 juin 2016. [Consulté, le 10 décembre 2016]. URL: http://www.afdb.org/fr/blogs/measuringthe-pulse-of-economic-transformation-in westafrica/post/industrialisation-in-west-africa-1-the-current-stateof-affairs-15806/ 